\title{
Maximizing value in opioid utilization: Is oxycodone immediate release a good option for pain management?
}

\author{
Opioid kullanımının değerini maksimize etmek: Hzzl salımlı oksikodon \\ ăgr tedavisinde iyi bir seçenek midir?
}

\author{
Joseph V. PERGOLIZZI, ${ }^{1}$ Gül KÖKNEL TALU, ${ }^{2}$ Gianpetrio ZMPONGA, ${ }^{3}$ Serdar ERDINE, ${ }^{2}$ \\ Robert TAYLOR, ${ }^{3}$ Burak AYAN, ${ }^{4}$ Robert B RAFFA ${ }^{5}$
}

\begin{abstract}
Summary
The modern approach to the management of pain involves optimizing all aspects of the process. This includes utilization of pharmacologic and non-pharmacologic modalities, consideration of patient characteristics, proper matching of the physiology of the pain with the analgesic's mechanism of action (pharmacodynamics, PD), and the onset and duration of action (pharmacokinetics, PK). No single agent or formulation satisfies all of the requirements for all patients. Aspirin and other non-steroidal anti-inflammatory drugs (NSAIDs) are effective options for inflammatory pain and, as is acetaminophen, for mild pain. Specialized agents are helpful for particular pains, such as for migraine headache. Opioids remain the standard option for severe pain. Although they are generally a safe and effective option, opioids can produce dose-limiting adverse effects and have abuse potential. The goal of pain therapy is thus to achieve the maximum pain relief with the least amount of opioid exposure. Against this background of measured approach to the use of analgesics, an immediate release (IR) oral formulation of the established opioid oxycodone has been developed to provide rapid onset of action and rate of titration, both of which could maximize temporal matching of dose with pain level and reduce total exposure to drug. This article considers the option of an immediate release (IR) oral formulation for the management of pain.
\end{abstract}

Key words: Opioid; oxycodone; pain management.

\section{Özet}

Ağrı tedavisine modern yaklaşım sürecin her yönüyle optimal düzeye getirilmesinden geçer. Bu yaklaşım farmakolojik olan ve olmayan yöntemlerin kullanılmasın, hastanın karakteristik özelliklerinin göz önüne alınasın, ağrı fizyolojisinin analjeziğin etki mekanizması (farmakodinamisi), etkisinin başlama anı ve süresi (farmakokinetiği) ile uygun biçimde eşleştirilmesini içerir. Herhangi bir tek ajan veya formülasyon hastaların tümünün her gereksinmesini karşılayamaz. Aspirin ve diğer steroit yapisında olmayan antienflamatuvar ilaçlar (NSAİI’ler) inflamatuvar ağrı, asetaminofen haffi ağrıda etkilidir. Özel ilaçlar migren baş ağrısı gibi spesifik ağrılarda etkilidir. Opioidler şiddetli ağrıda standart seçenek olmayı sürdürmektedir. Genellikle güvenli ve etkili seçenek olmalarına rağmen opioidler dozla sınırl advers etkilere neden olabildikleri gibi, kötïye kullanım potansiyele de sabiptirler. O halde ağrı tedavisinin amacı en düşük opioid dozuyla ağrının maksimum düzeyde yok edilmesini sağlamaktır. Bu analjezik kullanımına ilişkin yaklaşım temelinde, dozun ağrı düzeyiyle zamansal eşleşmesini maksimize edebilen ve ilaca total maruziyet seviyesini düşüren bilinen opioid oksikodonun hızlı salımlı (IR) ve hemen titre edilen oral formülasyonu geliştirilmiştir. Bu makale ağrı tedavisinde hızlı salmlı oral formülasyon (IR) seçeneğini göz önüne almaktadır.

Anahtar Kelimeler: Opioid; oksikodin; ağrı yönetimi. \footnotetext{
Medicine, Philadelphia, Pa; Nema Research Inc, Bonita Springs, Fl, USA;

${ }^{2}$ Department of Algology, Medical Faculty of Istanbul, Istanbul University, Turkey;

${ }^{3}$ Nema Research Inc, Bonita Springs, FI, USA;

${ }^{4}$ Bahçelievler State Hospital, Istanbul, Turkey;

${ }^{5}$ Department of Pharmaceutical Sciences, Temple University School of Pharmacy, Philadelphia, Pa, USA

Correspondence (iletişim): Dr. Robert Taylor. 3384 Woods Edge Circle, Suite 102, Bonita Springs, FL 34134 Florida, United States.

Tel: +1 - 239-5973564 e-mail (e-posta): rtaylor@nemaresearch.com
}

'Department of Medicine, Johns Hopkins University School of Medicine, Baltimore; Department of Pharmacology, Temple University School of 


\section{Introduction}

The selection of an appropriate analgesic product for a specific patient depends on the complex interplay of numerous factors, such as the patient's painful condition, his or her age and health, other drugs, the setting, accessibility and legal restrictions associated with specific agents, and even the patient's genetic background. Opioids have long been recognized as safe and effective agents to treat many painful conditions, including the World Health Organization's now-famous "pain ladder" which recognized opioid therapy as an important way to address moderate to severe pain associated with cancer. ${ }^{[1]}$ While oral morphine rapidly emerged as the "gold standard" in opioid analgesia, owing perhaps to its widespread availability and affordability, pain therapy is far from a "one size fits all" paradigm. In the past decades, numerous opioid agents have been added to the analgesic armamentarium. A new product for Turkey, an oral immediate-release (IR) oxycodone, available commercially in 5, 10, and 20 mg capsules, has been added.

Oxycodone is an established. First described clinically as early as $1917,,^{[2]}$ oxycodone's mechanism of action is, like morphine's primarily due to agonist action at mu-opioid-receptors (MOR), with perhaps some contribution involving kappa-opioid receptors pathways. Its liposolubility is similar to morphine's and its plasma protein binding (mainly to albumin) is around $40 \%$ to $50 \%$ (morphine is $38 \%)$. On the WHO pain ladder, oxycodone would be considered a "strong opioid." [1]

\section{Opioid metabolism}

The analgesic effect of opioids is due to their agonist action at both central and peripheral 7-transmembrane G protein-coupled receptor (7TM-GPCR) mu-opioid receptors. ${ }^{[3]}$ Some opioids may also interact with other opioid receptors, namely the kappa and delta receptors. Opioid agents bind to the receptors and ion channels and $2^{\text {nd }}$ messengers transduce the signal into inhibition of the ascending transmission of nociceptive information from periphery to spinal cord. At the same time, opioids also activate descending pathways (e.g., norepinephrine and serotonin), which work to modulate pain signals. These two simultaneous activities - inhibition of transmis- sion and modulation of signals — reduce or stop pain perception. Opioids also affect the body's limbic system which "interprets" or contextualizes pain.

The sometimes wide inter-patient variability in opioid response can be contributed to numerous factors. Opioid metabolism is governed by certain heritable factors, such that polymorphisms render individuals and sometimes certain ethnic groups more or less able to metabolize specific opioid agents. ${ }^{[4]}$ The patient's hepatic and renal status can influence opioid responsiveness because they govern how well the body can metabolize and eliminate opioids and their metabolites. ${ }^{[5]}$ Opioid metabolism is also affected by age ${ }^{[6]}$ and sex, ${ }^{[7-9]}$ although these influences are not fully elucidated. The mental health status of the patient may also influence the agent's effectiveness. ${ }^{[10]}$

Opioid analgesics are known to be safe and effective in the treatment of many acute and some chronic pain syndromes. ${ }^{[11-16]}$ They can be titrated to effect without ceiling effect and are generally not associated with end-organ damage even at elevated doses. [17] The dose-related side effects of opioids are well known and include sedation, drowsiness, somnolence, nausea, vomiting, dizziness, headache, and constipation. ${ }^{[18]}$ These adverse events may be mild and transient, but in some cases patients may find them sufficiently distressing to limit treatment. ${ }^{[19]}$ Respiratory depression is the major life-threatening adverse effect.

The metabolic pathways differ for various opioid agents. Oxycodone is metabolized by cytochrome CYP4503A (CYP3A4/5) and CYP2D6, although the former is the more dominant pathway. Genetic polymorphisms in CYP2D6 have resulted in patients being described as poor, intermediate, extensive, and ultra-rapid metabolizers of oxycodone. Among Caucasians, about $8 \%$ can be categorized as an oxycodone "poor metabolizer," while $90 \%$ or more are "extensive metabolizers" although metabolism in this group is somewhat variable. ${ }^{[20]}$ However, CYP2D6 does not appear to impact the analgesic effect of oxycodone, thus these different metabolizer classifications usually do not impact dosing.

Since oxycodone is metabolized in the liver, hepatic 
dysfunction may result in a higher volume of distribution and a correspondingly lower clearance rate of oxycodone. Oxycodone should be prescribed with caution in patients hepatic dysfunction; in end-stage liver failure the half-life of oxycodone can exceed 12 hours. ${ }^{[20]}$

Oxycodone produces metabolites (most notably oxymorphone and noroxymorphone), but the analgesic effect appears to reside primarily in the parent drug. ${ }^{[21]}$

Oxycodone is indicated for relief of moderate to severe pain ${ }^{[22]}$ and the IR oxycodone oral formulation was designed to allow for highly individualized, patient-tailored pain therapy. Oxycodone is the most frequently prescribed opioid analgesic in the United States and some European countries, ${ }^{[20]}$ although usage patterns for opioids tend to vary widely among nations. ${ }^{[23-25]}$ In evaluating the appropriate role of oral oxycodone IR, it is important to consider how pain is actually treated.

\section{Under-treatment of pain}

The American Cancer Society's initiative "Treat the Pain" reports that 2.4 million people world-wide died with untreated pain in 2012. ${ }^{[26]}$ It is estimated that in 78 nations around the world representing more than $40 \%$ of world population, analgesic use is not sufficient to cover even one quarter of the need. ${ }^{[27]}$ In 2013 in Turkey, there were 91.826 cancer deaths and $200 \mathrm{HIV}$-related deaths associated with moderate to severe pain and reportly $80 \%$ and $50 \%$, respectively, died without access to opioid analgesics. ${ }^{[28]}$

In a prospective, observational study of 3023 invasive cancer patients, $67 \%$ of patients reported pain at initial assessment and of that 33\% had not received any prescription analgesics. ${ }^{[29]}$ There was no significant change in prescribing in follow-up visits, that is, even over time, the proportion of patients with under-treated pain did not change. Undertreatment of pain may arise from a lack of clinician training in opioid use and titration, ${ }^{[30]}$ concern about legal regulations and liability in prescribing opioids, ${ }^{[31]}$ governmental restrictions and reimbursement issues, ${ }^{[32,33]}$ and poor communication between physician and patient. ${ }^{[33]}$ Besides clinician factors, patient factors may also contribute to sub- optimal analgesia. Just as clinicians are concerned about opioid abuse, ${ }^{[34]}$ patients may fear their own risk of addiction and refuse opioids. ${ }^{[35]}$ Patients may also be concerned about developing a tolerance to pain killers or suffering opioid-related side effects. ${ }^{[33]}$ Ethnic, cultural, and familial factors may also come into play and influence how the patient perceives pain and suffering.

While some pain goes entirely untreated, clinicians need also be concerned with under-treated or suboptimally managed pain. Barriers to optimally managed pain includel: inadequate pain diagnosis or pain intensity assessments, poor choice or dosing of analgesic agent, failure to recognize the multimechanistic nature of pain (such as not treating a strong neuropathic component), patient non-compliance, analgesic gaps, tolerance, and inadequate management of side effects, which can limit treatment. Chronic pain syndromes can change over time or with the underlying disease so that optimally managed pain can abruptly transition to poorly managed pain. Patients dealing with moderate to severe pain, whether in the acute setting or over the long term, require close clinical supervision to optimize their pain control.

Paramount to optimal pain control is the choice of analgesic agent. Analgesic agents fall into two broad categories: nonopioid agents (including acetaminophen, aspirin, and nonsteroidal anti-inflammatory drugs or NSAIDs) and opioids. In addition to these agents, combination therapy (such as fixed-dose products combining acetaminophen and a smaller amount of opioid) and adjuvant agents (such as tricyclic antidepressants, anticonvulsants, and muscle relaxers, among others) can be considered.

Despite the known effectiveness of opioids for the relief of many moderate to severe pain syndromes, opiophobia (the fear of prescribing opioids) may contribute to under-treatment of pain. ${ }^{[36,37]}$ To be sure, any opioid therapy carries a certain degree of risk for inappropriate use, misuse, abuse, addiction, diversion, and tolerance. ${ }^{[38-40]}$ The inappropriate use of opioids may be thought of as a continuum of behaviors, ranging from non-compliance (such as skipping a dose or doubling up on a bad day) at one extreme to addiction and drug diversion at the other. ${ }^{[11,42]}$ Between these extremes falls much of what 
might be considered opioid misuse: taking the drugs recreationally (abuse), taking them to manage emotional or psychological pain, or taking them to treat real but undiagnosed and non-medically-managed pain. ${ }^{[43,44]}$ Oral IR oxycodone is reported to be one of the most frequently abused opioids, ${ }^{[45]}$ but these data were obtained from patients entering drug rehabilitation and not the general pain population at large. This likely reflects a preference among drug abusers for oral IR formulations rather than the fact that IR agents are inherently more addictive to patients under clinical supervision. To the best of our knowledge, the literature does not report on the abuse potential specifically for injectable IR oxycodone.

\section{Selecting the right opioid: when can IR oxycodone be a good choice?}

Oxycodone is indicated for the treatment of moderate to severe pain and is appropriate for postsurgical pain, acute pain syndromes, and cancer pain. ${ }^{[2]}$ Although similar in effect and tolerability to other opioids, there are unique attributes to oxycodone (like any other opioid) that may make it more or less appropriate for a given patient. In the United States, oxycodone is the most-prescribed opioid, ${ }^{[20]}$ although this usage pattern is not observed in other countries. ${ }^{[46]}$

Oxycodone, both as monotherapy and in combination, has demonstrated effectiveness for the treatment of postsurgical pain, ${ }^{[47]}$ cancer pain, ${ }^{[15,48]}$ neuropathic pain, ${ }^{[49-51]}$ and acute pain syndromes. ${ }^{[52]}$ Although the long-term use of any opioid remains controversial for the treatment of chronic pain syndromes, the literature reports on the use of oxycodone for managing non-cancer chronic pain. ${ }^{[53-55]}$ While clinical caution is urged in prescribing opioids (including but not limited to oxycodone) for managing severe headache pain, they are widely prescribed in the emergency room setting for this use. ${ }^{[56]}$

When prescribing oxycodone, the clinician must consider the other drugs and supplements the patient is taking, since pharmacokinetic drug-drug interactions can occur. ${ }^{[57,58]}$ Because of the metabolic pathways used by oxycodone (CYP3A4 and CYP2D6), CYP3A4 inducers, such as rifampicin, rofexocib, St. John's wort, and others, may increase oxycodone metabolism, resulting in a decrease in its analgesic effectiveness. ${ }^{[59,60]}$ On the other hand, CYP3A4 inhibitors, such as grapefruit juice, erythromycin, codeine, omeprazole, quinidine, and others, can potentiate the effects of oxycodone. It appears that transporter proteins play a role in such oxycodone drug-drug interactions, ${ }^{[59]}$ but the mechanisms are not fully elucidated.

Head-to-head comparisons of specific opioid analgesic products exist in the literature but are not always informative, in that many factors can confound findings: marked inter-patient variability in opioid responsiveness, opioid dosing, and opioid potency along with the subjective nature of pain and pain relief. Some recent clinical trials and reviews/ meta-analyses show that oxycodone is similar in effectiveness to morphine, ${ }^{[61-64]}$ and hydromorphone.

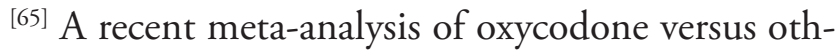
er strong opioids $(n=37$ studies and 7 randomized clinical trials, 613 cancer patients with moderate to severe pain) found in 4 studies that oxycodone was significantly better than other strong opioids in reducing pain intensity in cancer patients and in seven studies there was a significant difference favoring oxycodone for effective pain relieve in cancer pain. ${ }^{[16]}$ In a study of acute pain associated with bone fracture, oxycodone combined with acetaminophen was found to be as effective as morphine monotherapy in relieving pain. ${ }^{[52]}$ Oral oxycodone was found to be effective in pain management following Cesarean section ${ }^{[6]]}$ and intravenous oxycodone was shown effective in managing pain following hysterectomy. ${ }^{[67]}$ Oral oxycodone was also reported to be a safe, effective, and cost-effective alternative to patient-controlled analgesia (PCA) systems using opioids for control of postoperative pain. ${ }^{[68]}$

Oxycodone is available in intravenous, subcutaneous, intramuscular, and oral formulations. Route of administration may be an important consideration in prescribing: intravenous drugs are more expensive and require hospitalization, while oral agents are generally more inexpensive and convenient. Oral IR formulations offer rapid time to peak concentration in a product that can be self- administered quickly and conveniently by the patient. Oral agents offer convenience as well, but may be precluded if the patient is dysphagic ${ }^{[69]}$ or if they contribute to a substantial pill burden. 

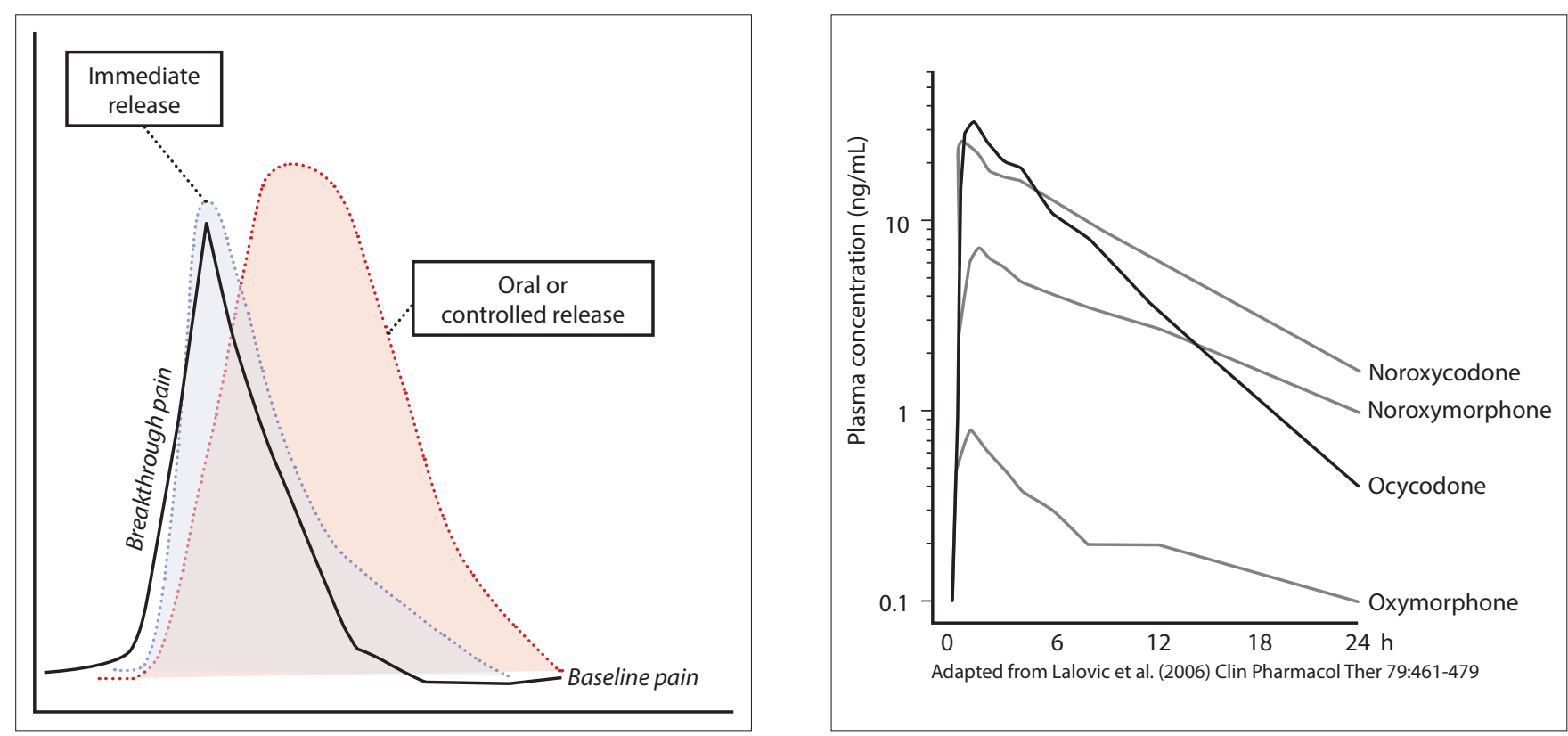

Figure 1. Breakthrough pain typically occurs spontaneously against a background of pain control, has a rapid onset, and is transient. Oral or controlled-release formulations of analgesics can yield pain-relief profiles (shaded regions) that are out of phase with the level of pain (i.e., too slow in onset and longer than needed). Intravenous formulations can provide a better match of dosing with level of pain, reducing the opioid load.

Oral IR oxycodone was designed to allow for individualized patient-tailored pain therapy. IR oxycodone has an onset of action of 15 to 30 minutes. ${ }^{[70]}$ To convert equianalgesic daily doses, hydrocodone and methadone have a 1.0 conversion ratio (that is, $10 \mathrm{mg}$ of hydrocodone is equianalgesic to $10 \mathrm{mg}$ of oral oxycodone), while morphine has a 0.5 conversion ratio (such that oral morphine $20 \mathrm{mg}$ is equianalgesic to $10 \mathrm{mg}$ of oral oxycodone).

All opioids, including oxycodone, are associated with side effects, which may be severe enough to adversely impact the patient's quality of life or even limit treatment. ${ }^{[71]}$ Side effects may in some cases be manageable, for example with a bowel regimen for constipation or antiemetic therapy for nausea. Patients should be advised about tolerability issues with opioids and encouraged to report side effects for optimal management or, if necessary, opioid rotation or discontinuation. The adverse reactions that occur with IR oxycodone are similar to those of other strong opioids.

\section{The role of IR oxycodone}

In two trials, it was found that dose titration with oral oxycodone could be accomplished as readily with the IR formulations as the controlled-release (CR), ${ }^{[72]} \mathrm{al}-$ though IR formulations are often used preferentially for dose titration for patients who require aroundthe-clock analgesia. Among cancer pain patients, $79 \%$ achieved stable pain relief with acceptable levels of side effects using the IR formulation (versus 92\% with the CR oxycodone), while among non-cancer patients, 96\% could be titrated with IR oxycodone compared to $87 \%$ with CR oxycodone. ${ }^{[72]}$

IR oxycodone may be an important agent for the control of breakthrough pain (BTP), defined as a transient and clinically significant pain that flares over a background of baseline pain that is adequately controlled on an analgesic regimen. ${ }^{[73]}$ Although BTP is more closely associated with cancer pain, it also occurs in non-cancer pain syndromes. ${ }^{[74,75]}$ In a recent study of 134 cancer pain patients, BTP episodes were reported by $30.5 \% .{ }^{[76]}$ In a retrospective study of consecutive pain patients at a single center, $56.4 \%$ of patients overall reported severe BTP; in cancer pain patients, $70.3 \%$ reported severe BTP. ${ }^{[77]}$ These numbers may actually under-report the phenomenon, in that the definition of BTP has recently been challenged to include "BTP-like flares" in patients who do not have chronic background pain controlled by opioids. ${ }^{[78]}$ This expanded definition would increase the numbers, possibly by as much as $10 \% .{ }^{[78]}$

BTP may occur multiple times per day and its oc- 
currence can be unpredictable; pain onset is typically rapid, reaching maximum severity in as few as five minutes. Although BTP episodes are typically brief, that is 30 minutes or less, they may last hours. [79] BTP is challenging to manage and opioids are generally prescribed as rescue medication. ${ }^{[80,81]}$ BTP can decrease quality of life, cause suffering to the patient and distress to his family, reduce productivity, increase social isolation, and utilize healthcare resources. ${ }^{[82,83]}$ When assessing pain patients, clinicians should be mindful of the prevalence of BTP. Patients require education about the nature of BTP and how it can be managed, as it can cause considerable anxiety. A rapid onset of pain relief is better achieved with the i.v route of administration than it is with a slower route of administration, such as oral or controlled-release (Figure 1).

When using oral IR oxycodone for BTP, one recommend rule of thumb is to use the 24-hour oral dose of oxycodone and prescribe a BTP dose of roughly $10 \%$ to $20 \%$ of that dose. ${ }^{[84]}$ For example, if the patient takes $80 \mathrm{mg}$ of oral oxycodone per day, a BTP dose of oral IR oxycodone would be around 8 to 16 $\mathrm{mg}$ rounded to 10 or $15 \mathrm{mg}$. BTP may worsen with disease progression, so BTP doses may require further up-titration to manage increasingly severe BTP episodes.

IR oxycodone is also an appropriate opioid for use in other pain syndromes. Its formulation allows for easy titration, such that an appropriate stable dose can be reached more easily and conveniently in $5 \mathrm{mg}$ steps.

\section{Tolerance and abuse}

Tolerance refers to the need for escalating doses to provide equivalent levels of analgesia. Tolerance is not natural physiological phenomenon nor does it increase the patient's risk for addiction or abuse. ${ }^{[85]}$ Nevertheless, opioid tolerance should be accurately diagnosed and then managed with prudently increased doses of the analgesic or, in some cases, opioid rotation. Clinicians may be wary about managing tolerance, as the patient may exhibit similar behaviors as an addicted patient, making increasingly assertive demands for more opioids and complaining of unrelenting pain. For that reason, tolerance is sometimes called "pseudoaddiction." ${ }^{[86]}$ A tolerant patient truly needs a higher dose of analgesia for pain control, but an addicted patient is seeking the drug out of a craving. The development of addiction to opioid pain relievers in properly managed pain patients is reported to be rare, ${ }^{[87]}$ but it can occur. The appropriate treatment of tolerance is to judiciously increase the drug dose to achieve optimal analgesia; the appropriate treatment of addiction is to taper the patient off the drug and treat the pain in some other way.

To mitigate the risk of abuse, clinicians prescribing opioids should do so only after a thorough patient history is taken. Patients with a history of drug or alcohol abuse, and even those with a familial (but not personal) history of substance abuse, are at elevated risk for drug abuse. ${ }^{[88]}$ The patient may develop risk factors for opioid abuse over time, so patients prescribed opioids should be supervised closely. Urine drug screening may be a useful tool to determine if the patient is taking the prescribed medication(s) and appropriately ensure he or she is not taking any illicit drugs. ${ }^{\left[{ }^{[9]}\right.}$ Aberrant drug-taking behaviors may be indicators that the patient is taking the drugs inappropriately. ${ }^{[90]}$ There is some evidence that women may exhibit different aberrant drug-seeking behaviors than men. ${ }^{[1]}$

\section{Tailoring pain therapy to meet the individual pa- tient's unique needs}

Tailored therapy is by definition patient-centric, so the patient's individual pain syndrome must first be understood. This includes identifying the pain as acute or chronic and whether it is associated with a malignancy. The underlying cause of the pain must be sought, although in some cases of chronic pain, the etiology may be elusive. The patient should be interviewed and asked to identify the location of all pain sites. Many patients will present with multiple sites of pain and it is important for the clinician to note that the pain sites may not be related; for example, a cancer patient may have sites that relate to cancer pain and other pain related to osteoarthritis for example. It is not unusual for chronic pain patients to suffer diffuse pain (difficult to pinpoint the exact site of pain) or pain that migrates from site to site.

The patient should be interviewed thoroughly but compassionately about each pain site and asked to describe the pain. Most patients have a limited ability to describe their pain, so the clinician may wish 
to prompt the patient as to whether the pain starts and stops suddenly, if it comes and goes with any observed conditions (such as movement), if it is mild or severe, and if the pain could be described as dull, throbbing, sharp, electrical, stabbing, or tingling. Clinicians should also ask the patient about any pain sites or areas of the body that are numb, lack much feeling, or experience "pins and needles" sensations. The characteristics of pain will help the clinician identify whether it is, for example, nociceptive, neuropathic, or visceral; many painful conditions involve mixed mechanisms. Patients should also be asked what prescription or over-the-counter products they take or have taken for pain and how effective such treatments have been and what exacerbates or relieves their pain.

For patients considered for opioid therapy, screening tools exist to help define risk. ${ }^{\left[{ }^{[2,93]}\right.}$ As stated earlier, patients are at elevated risk for opioid misuse and abuse if they have a personal or familial history of substance abuse; risk is further increased if they have mental health disorders. ${ }^{[94,95]}$ Increasingly, physicians face the conundrum of treating a patient with both a legitimate painful condition and prominent risk factors for opioid abuse. It goes beyond the scope of this article to address these prescribing conditions, but the literature increasingly has tackled the challenging and increasingly relevant topic of treating high-risk pain patients. ${ }^{[96-100]}$

Pain tends to be a dynamic condition, and pain therapy must be regularly reviewed and adjusted as needed. To this end, the physician must understand the expected trajectory of the pain syndrome (for instance, postsurgical pain has a different natural history than cancer pain), the anticipated role the underlying disease and possible comorbidities might play in the pain, and ongoing treatments. Cancer patients, for example, may experience permanent or transient neuropathic pain associated with certain forms of chemotherapy. ${ }^{[101]}$

The final choice of agents for an individual patient depends on many factors, including: the type of pain syndrome, pain intensity and severity, the patient's ability to self-manage the pain (some patients make extensive and effective use of nonpharmacological options), the availability of a given drug, reimburse- ment, legal and regulatory issues, cost-effectiveness, prescriber preference, and patient satisfaction. Since pain changes over time, drug therapy must be reviewed frequently and adjustments made to achieve and maintain optimal analgesia.

Finally, patient education and open lines of communication are essential for effective pain control. The patient should be informed about the nature of pain and what he/she can expect-and should not expect-from pain therapy. Physicians should inform patients about the potential risks as well as benefits with different pain treatments. Patients should be advised about the likelihood and nature of possible adverse events, since many can be controlled if they are promptly reported. It is the experience of the authors that some pain patients hold one of two extreme views about pain: either that pain can be entirely controlled (ideally with one single pill) or that there is nothing that can be done about it. Managing the patient's expectations involves preparing the patient that pain control is safe and possible but that total freedom from pain may not be achievable.

The prescriber must also determine the appropriate route of administration for the drug and the desired formulation. Oxycodone IR provides an important option, in that it offers rapid onset of action and fast dose titration, important factors for certain pain patients.

\section{Conclusion}

Oxycodone is an established analgesic agent which has demonstrated effectiveness in a variety of pains, including chronic nonmalignant pain. Oral oxycodone IR formulation has been developed in recognition many patients dealing with moderate to severe pain require a rapid onset of action and rapid dose titration. Oxycodone is generally recognized as a very effective analgesic and has been favorably compared to morphine and hydrocodone. Oxycodone is associated with the same side effects as other strong opioids, many of which can be managed but some of which can be treatment limiting. No one single analgesic and no single opioid is right for every patient. The addition of oral IR oxycodone to the analgesic armamentarium is a useful addition to better tailor analgesic therapy for individual patients. 


\section{Acknowledgements}

Dr. Pergolizzi is a consultant for Grünenthal, Mundi Pharma, Purdue Pharma LP, and Actavis. Prof. Raffa is a speaker, consultant, and/or basic science investigator for several pharmaceutical companies involved in analgesics research, but receives no royalty (cash or otherwise) from the sale of any product. This article was prepared with editorial assistance from LeQ Medical, Angleton, Texas. This article was based on a lecture given at $13^{\text {th }}$ National Pain Congress June 5-8 2014 Istanbul, Turkey

\section{Conflict-of-interest issues regarding the authorship or article: None declared.}

\section{Peer-rewiew: Externally peer-reviewed.}

\section{References}

1. World Health Organization. WHO's pain ladder for adults. 1988; http://www.who.int/cancer/palliative/painladder/ en/. Accessed 7 May, 2013.

2. Kalso E. Oxycodone. J Pain Symptom Manage 2005;29(5 Suppl):47-56. CrossRef

3. Smith H. Introduction to Opioids. New York: Oxford University Press; 2013.

4. Stamer UM, Zhang L, Book M, Lehmann LE, Stuber F, Musshoff F. CYP2D6 genotype dependent oxycodone metabolism in postoperative patients. PLoS One 2013;8(3):60239.

5. Smith H, Bruckenthal P. Implications of opioid analgesia for medically complicated patients. Drugs Aging 2010;27(5):417-33. CrossRef

6. Pergolizzi J, Böger RH, Budd K, Dahan A, Erdine S, Hans G, et al. Opioids and the management of chronic severe pain in the elderly: consensus statement of an International Expert Panel with focus on the six clinically most often used World Health Organization Step III opioids (buprenorphine, fentanyl, hydromorphone, methadone, morphine, oxycodone). Pain Pract 2008;8(4):287-313. CrossRef

7. Chan S, Edwards SR, Wyse BD, Smith MT. Sex differences in the pharmacokinetics, oxidative metabolism and oral bioavailability of oxycodone in the Sprague-Dawley rat. Clin Exp Pharmacol Physiol 2008;35(3):295-302. CrossRef

8. Han H, Kass PH, Wilsey BL, Li CS. Age, gender, and earlier opioid requirement associations with the rate of dose escalation in long-term opioid therapy. J Opioid Manag 2013;9(2):129-38. CrossRef

9. Zacny JP. Morphine responses in humans: a retrospective analysis of sex differences. Drug Alcohol Depend 2001;63(1):23-8. CrossRef

10. Christo PJ, Grabow TS, Raja SN. Opioid effectiveness, addiction, and depression in chronic pain. Adv Psychosom Med 2004;25:123-37. CrossRef

11. Chou R. 2009 Clinical Guidelines from the American Pain Society and the American Academy of Pain Medicine on the use of chronic opioid therapy in chronic noncancer pain: what are the key messages for clinical practice? Pol Arch Med Wewn 2009;119(7-8):469-77.
12. Caraceni A, Hanks G, Kaasa S, Bennett MI, Brunelli C, Cherny $\mathrm{N}$, et al. Use of opioid analgesics in the treatment of cancer pain: evidence-based recommendations from the EAPC. Lancet Oncol 2012;13(2):58-68. CrossRef

13. Zhang W, Moskowitz RW, Nuki G, Abramson S, Altman RD, Arden $\mathrm{N}$, et al. OARSI recommendations for the management of hip and knee osteoarthritis, Part II: OARSI evidencebased, expert consensus guidelines. Osteoarthritis Cartilage 2008;16(2):137-62. CrossRef

14. Basurto Ona X, Rigau Comas D, Urrútia G. Opioids for acute pancreatitis pain. Cochrane Database Syst Rev 2013;7:CD009179. CrossRef

15. King SJ, Reid C, Forbes K, Hanks G. A systematic review of oxycodone in the management of cancer pain. Palliat Med 2011;25(5):454-70. CrossRef

16. Wang YM, Liu ZW, Liu JL, Zhang L. Efficacy and tolerability of oxycodone in moderate-severe cancer-related pain: A meta-analysis of randomized controlled trials. Exp Ther Med 2012;4(2):249-54. CrossRef

17. Kalso E, Edwards JE, Moore RA, McQuay HJ. Opioids in chronic non-cancer pain: systematic review of efficacy and safety. Pain 2004;112(3):372-80. CrossRef

18. Mercadante S. Prospects and challenges in opioid analgesia for pain management. Curr Med Res Opin 2011;27(9):17413. CrossRef

19. Abramowitz L, Béziaud N, Labreze L, Giardina V, Caussé C, Chuberre $B$, et al. Prevalence and impact of constipation and bowel dysfunction induced by strong opioids: a crosssectional survey of 520 patients with cancer pain: DYONISOS study. J Med Econ 2013;16(12):1423-33. CrossRef

20. Kokki H, Kokki M, Sjövall S. Oxycodone for the treatment of postoperative pain. Expert Opin Pharmacother 2012;13(7):1045-58. CrossRef

21. Klimas R, Witticke D, El Fallah S, Mikus G. Contribution of oxycodone and its metabolites to the overall analgesic effect after oxycodone administration. Expert Opin Drug Metab Toxicol 2013;9(5):517-28. CrossRef

22. Medline Plus. Oxycodone. 2013; http://www.nlm.nih.gov/ medlineplus/druginfo/meds/a682132.html. Accessed 3 July, 2014.

23. Duthey B, Scholten W. Adequacy of opioid analgesic consumption at country, global, and regional levels in 2010, its relationship with development level, and changes compared with 2006. J Pain Symptom Manage 2014;47(2):28397. CrossRef

24. Group PPS. Opioid Consumption Data, Countries. 2013; http://www.painpolicy.wisc.edu/countryprofiles. Accessed Feb 8, 2014.

25. Kotlinska-Lemieszek A, Paulsen O, Kaasa S, Klepstad P. Polypharmacy in patients with advanced cancer and pain: a European cross-sectional study of 2282 patients. J Pain Symptom Manage 2014;48(6):1145-59. CrossRef

26. Treat the Pain. Treat the Pain. 2014; http://www.treatthepain.org/. Accessed 23 June, 2014.

27. Treat the Pain. Data. 2014; http://www.treatthepain.org/ data.html. Accessed 23 June, 2014.

28. Treat the Pain. Turkey. Country Snapshot 2014; http://www. treatthepain.org/Assets/CountryReports/Turkey.pdf. Accessed 23 June, 2014.

29. Fisch MJ, Lee JW, Weiss M, Wagner LI, Chang VT, Cella D, et al. Prospective, observational study of pain and analgesic prescribing in medical oncology outpatients with 
breast, colorectal, lung, or prostate cancer. J Clin Oncol 2012;30(16):1980-8. CrossRef

30. Mercadante S. Opioid titration in cancer pain: a critical review. Eur J Pain 2007;11(8):823-30. CrossRef

31. Gilson AM, Maurer MA, Joranson DE. State medical board members' beliefs about pain, addiction, and diversion and abuse: a changing regulatory environment. J Pain 2007;8(9):682-91. CrossRef

32. Primm BJ, Perez L, Dennis GC, Benjamin L, Clark W, Keough $\mathrm{K}$, et al. Managing pain: The Challenge in Underserved Populations: Appropriate Use Versus Abuse and Diversion. J Natl Med Assoc 2004;96(9):1152-61.

33. Glajchen M. Chronic pain: treatment barriers and strategies for clinical practice. J Am Board Fam Pract 2001;14(3):211-8.

34. Manchikanti L. Prescription drug abuse: what is being done to address this new drug epidemic? Testimony before the Subcommittee on Criminal Justice, Drug Policy and Human Resources. Pain Physician 2006;9(4):287-321.

35. McCracken LM, Hoskins J, Eccleston C. Concerns about medication and medication use in chronic pain. J Pain 2006;7(10):726-34. CrossRef

36. Rhodin A. The rise of opiophobia: is history a barrier to prescribing? J Pain Palliat Care Pharmacother 2006;20(3):31-2.

37. Rupp T, Delaney KA. Inadequate analgesia in emergency medicine. Ann Emerg Med 2004;43(4):494-503. CrossRef

38. Brennan MJ, Stanos S. Strategies to optimize pain management with opioids while minimizing risk of abuse. PM R 2010;2(6):544-58. CrossRef

39. Manchikanti L, Giordano J, Boswell MV, Fellows B, Manchukonda R, Pampati V. Psychological factors as predictors of opioid abuse and illicit drug use in chronic pain patients. J Opioid Manag 2007;3(2):89-100.

40. Sullivan MD, Von Korff M, Banta-Green C, Merrill JO, Saunders K. Problems and concerns of patients receiving chronic opioid therapy for chronic non-cancer pain. Pain 2010;149(2):345-53. CrossRef

41. Compton WM, Volkow ND. Abuse of prescription drugs and the risk of addiction. Drug Alcohol Depend 2006;83 Suppl 1:4-7. CrossRef

42. Passik SD. Issues in long-term opioid therapy: unmet needs, risks, and solutions. Mayo Clin Proc 2009;84(7):593-601.

43. Del Fabbro E. Assessment and management of chemical coping in patients with cancer. J Clin Oncol 2014;32(16):1734-8.

44. Passik SD, Lowery A. Psychological variables potentially implicated in opioid-related mortality as observed in clinical practice. Pain Med 2011;12 Suppl 2:36-42. CrossRef

45. Butler SF, Black RA, Cassidy TA, Dailey TM, Budman SH. Abuse risks and routes of administration of different prescription opioid compounds and formulations. Harm Reduct J 2011;8:29. CrossRef

46. Freud T, Sherf M, Battat E, Vardy D, Shvartzman P. Patterns of opioid consumption in cancer patients. Isr Med Assoc J 2013;15(2):89-93.

47. Gimbel J, Ahdieh H. The efficacy and safety of oral immediate-release oxymorphone for postsurgical pain. Anesth Analg 2004;99(5):1472-7. CrossRef

48. Ahmedzai SH, Nauck F, Bar-Sela G, Bosse B, Leyendecker P, Hopp M. A randomized, double-blind, active-controlled, double-dummy, parallel-group study to determine the safety and efficacy of oxycodone/naloxone prolongedrelease tablets in patients with moderate/severe, chronic cancer pain. Palliat Med 2012;26(1):50-60. CrossRef

49. Gatti A, Sabato E, Di Paolo AR, Mammucari M, Sabato AF. Oxycodone/paracetamol: a low-dose synergic combination useful in different types of pain. Clin Drug Investig 2010;30 Suppl 2:3-14. CrossRef

50. Gatti A, Sabato AF, Occhioni R, Colini Baldeschi G, Reale C. Controlled-release oxycodone and pregabalin in the treatment of neuropathic pain: results of a multicenter Italian study. Eur Neurol 2009;61(3):129-37. CrossRef

51. Hanna M, O'Brien C, Wilson MC. Prolonged-release oxycodone enhances the effects of existing gabapentin therapy in painful diabetic neuropathy patients. Eur J Pain 2008;12(6):804-13. CrossRef

52. Zare MA, Ghalyaie AH, Fathi M, Farsi D, Abbasi S, Hafezimoghadam P. Oral oxycodone plus intravenous acetaminophen versus intravenous morphine sulfate in acute bone fracture pain control: a double-blind placebo-controlled randomized clinical trial. Eur J Orthop Surg Traumatol 2014;24(7):1305-9. CrossRef

53. Mercadante S, Giarratano A. Combined oral prolongedrelease oxycodone and naloxone in chronic pain management. Expert Opin Investig Drugs 2013;22(1):161-6. CrossRef

54. Scharnagel R, Kaiser U, Schütze A, Heineck R, Gossrau G, Sabatowski R. Chronic non-cancer-related pain. Long-term treatment with rapid-release and short-acting opioids in the context of misuse and dependency. [Article in German] Schmerz 2013;27(1):7-19. [Abstract] CrossRef

55. Taylor R Jr, Raffa RB, Pergolizzi JV Jr. Controlled release formulation of oxycodone in patients with moderate to severe chronic osteoarthritis: a critical review of the literature. J Pain Res 2012;5:77-87.

56. Friedman BW, West J, Vinson DR, Minen MT, Restivo A, Gallagher EJ. Current management of migraine in US emergency departments: An analysis of the National Hospital Ambulatory Medical Care Survey. Cephalalgia 2014 Jun 19.

57 Pergolizzi JV. Quantifying the impact of drug-drug interactions associated with opioids. Am J Manag Care 2011;17 Suppl 11:288-92.

58. Pergolizzi JV Jr, Labhsetwar SA, Puenpatom RA, Joo S, BenJoseph RH, Summers KH. Prevalence of exposure to potential CYP450 pharmacokinetic drug-drug interactions among patients with chronic low back pain taking opioids. Pain Pract 2011;11(3):230-9. CrossRef

59. Heiskanen T, Kalso E. Non-analgesic effects of opioids: interactions between opioids and other drugs. Curr Pharm Des 2012;18(37):6079-89. CrossRef

60. Söderberg Löfdal KC, Andersson ML, Gustafsson LL. Cytochrome P450-mediated changes in oxycodone pharmacokinetics/pharmacodynamics and their clinical implications. Drugs 2013;73(6):533-43. CrossRef

61. Pedersen KV, Olesen AE, Drewes AM, Osther PJ. Morphine versus oxycodone analgesia after percutaneous kidney stone surgery: a randomised double blinded study. Urolithiasis 2013:41(5):423-30. CrossRef

62. Reid CM, Martin RM, Sterne JA, Davies AN, Hanks GW. Oxycodone for cancer-related pain: meta-analysis of randomized controlled trials. Arch Intern Med 2006;166(8):837-43.

63. Koyyalagunta D, Bruera E, Solanki DR, Nouri KH, Burton AW, Toro MP, et al. A systematic review of randomized trials on the effectiveness of opioids for cancer pain. Pain Physician 2012;15(3 Suppl):ES39-58.

64. Rothwell MP, Pearson D, Hunter JD, Mitchell PA, Gra- 
ham-Woollard T, Goodwin L, et al. Oral oxycodone offers equivalent analgesia to intravenous patient-controlled analgesia after total hip replacement: a randomized, singlecentre, non-blinded, non-inferiority study. $\mathrm{Br} J$ Anaesth 2011;106(6):865-72. CrossRef

65. Yu S, Yu L, Hou Y, Han JH, Richards H. Safety and efficacy of once-daily hydromorphone extended-release versus twicedaily oxycodone $\mathrm{HCl}$ controlled release in cancer pain: a phase 3, randomized, double-blind, multi-center study in Chinese patients. Singapore: 5th Assoication of South-East Asian Pain Societies Conference; 2013;2-5.

66. Dieterich M, Müller-Jordan K, Stubert J, Kundt G, Wagner K, Gerber B. Pain management after cesarean: a randomized controlled trial of oxycodone versus intravenous piritramide. Arch Gynecol Obstet 2012;286(4):859-65. CrossRef

67. Lenz H, Sandvik L, Qvigstad E, Bjerkelund CE, Raeder J. A comparison of intravenous oxycodone and intravenous morphine in patient-controlled postoperative analgesia after laparoscopic hysterectomy. Anesth Analg 2009;109(4):1279-83. CrossRef

68. Ho HS. Patient-controlled analgesia versus oral controlledrelease oxycodone - are they interchangeable for acute postoperative pain after laparoscopic colorectal surgeries? Oncology 2008;74 Suppl 1:61-5. CrossRef

69. Pergolizzi JV Jr, Taylor R Jr, Nalamachu S, Raffa RB, Carlson DR, Varanasi RK, et al. Challenges of treating patients with chronic pain with dysphagia (CPD): physician and patient perspectives. Curr Med Res Opin 2014;30(2):191-202. CrossRef

70. Lugo RA, Kern SE. The pharmacokinetics of oxycodone. J Pain Palliat Care Pharmacother 2004;18(4):17-30. CrossRef

71. Anastassopoulos KP, Chow W, Ackerman SJ, Tapia C, Benson C, Kim MS. Oxycodone-related side effects: impact on degree of bother, adherence, pain relief, satisfaction, and quality of life. J Opioid Manag 2011;7(3):203-15. CrossRef

72. Salzman RT, Roberts MS, Wild J, Fabian C, Reder RF, Goldenheim PD. Can a controlled-release oral dose form of oxycodone be used as readily as an immediate-release form for the purpose of titrating to stable pain control? J Pain Symptom Manage 1999;18(4):271-9. CrossRef

73. Portenoy RK, Payne D, Jacobsen P. Breakthrough pain: characteristics and impact in patients with cancer pain. Pain 1999;81(1-2):129-34. CrossRef

74. Portenoy RK, Bennett DS, Rauck R, Simon S, Taylor D, Brennan $\mathrm{M}$, et al. Prevalence and characteristics of breakthrough pain in opioid-treated patients with chronic noncancer pain. J Pain 2006;7(8):583-91. CrossRef

75. Højsted J, Nielsen PR, Eriksen J, Hansen OB, Sjøgren P. Breakthrough pain in opioid-treated chronic non-malignant pain patients referred to a multidisciplinary pain centre: a preliminary study. Acta Anaesthesiol Scand 2006;50(10):1290-6.

76. Kurita GP, Tange UB, Farholt $H$, Sonne NM, Strömgren $A S$, Ankersen $L$, et al. Pain characteristics and management of inpatients admitted to a comprehensive cancer centre: a cross-sectional study. Acta Anaesthesiol Scand 2013;57(4):518-25. CrossRef

77. Gatti A, Mediati RD, Reale C, Cuomo A, Vellucci R, Russo G, et al. Breakthrough pain in patients referred to pain clinics: the Italian pain network retrospective study. Adv Ther 2012;29(5):464-72. CrossRef

78. Gatti A, Gentili M, lorno V, Mammucari M, Tufaro G, Lazzari $M$, et al. Beyond the traditional definition of breakthrough pain: an observational study. Adv Ther 2013;30(3):298-305.
79. Davies A, Zeppetella G, Andersen S, Damkier A, Vejlgaard T, Nauck F, et al. Multi-centre European study of breakthrough cancer pain: pain characteristics and patient perceptions of current and potential management strategies. Eur J Pain 2011;15(7):756-63. CrossRef

80. Webber K, Davies AN, Cowie MR. Breakthrough pain: a qualitative study involving patients with advanced cancer. Support Care Cancer 2011;19(12):2041-6. CrossRef

81. Zeppetella G, Davies AN. Opioids for the management of breakthrough pain in cancer patients. Cochrane Database Syst Rev 2013 Oct 21;10:CD004311. CrossRef

82. Portenoy RK, Bruns D, Shoemaker B, Shoemaker SA. Breakthrough pain in community-dwelling patients with cancer pain and noncancer pain, part 2: impact on function, mood, and quality of life. J Opioid Manag 2010;6(2):109-16. CrossRef

83. Portenoy RK, Bruns D, Shoemaker B, Shoemaker SA. Breakthrough pain in community-dwelling patients with cancer pain and noncancer pain, part 1: prevalence and characteristics. J Opioid Manag 2010;6(2):97-108. CrossRef

84. NCCN. Adult Cancer Pain. NCCN Clinical Practice Guidelines in Oncology (NCCN Guidelines) 2014; Version 2.2014. Available at: http://www.nccn.org/professionals/physician_gls/ PDF/pain.pdf. Accessed 4 July, 2014.

85. Dumas EO, Pollack GM. Opioid tolerance development: a pharmacokinetic/pharmacodynamic perspective. AAPS J 2008;10(4):537-51. CrossRef

86. Bell K, Salmon A. Pain, physical dependence and pseudoaddiction: redefining addiction for 'nice' people? Int J Drug Policy 2009;20(2):170-8. CrossRef

87. Portenoy RK, Savage SR. Clinical realities and economic considerations: special therapeutic issues in intrathecal therapy--tolerance and addiction. J Pain Symptom Manage 1997;14(3 Suppl):27-35. CrossRef

88. Pergolizzi JV Jr, Gharibo C, Passik S, Labhsetwar S, Taylor R $J \mathrm{~J}$, Pergolizzi JS, et al. Dynamic risk factors in the misuse of opioid analgesics. J Psychosom Res 2012;72(6):443-51. CrossRef

89. Pergolizzi J, Pappagallo M, Stauffer J, Gharibo C, Fortner N, De Jesus MN, et al. The role of urine drug testing for patients on opioid therapy. Pain Pract 2010;10(6):497-507. CrossRef

90. Chou R, Fanciullo GJ, Fine PG, Miaskowski C, Passik SD, Portenoy RK. Opioids for chronic noncancer pain: prediction and identification of aberrant drug-related behaviors: a review of the evidence for an American Pain Society and American Academy of Pain Medicine clinical practice guideline. J Pain 2009;10(2):131-46. CrossRef

91. Back SE, Payne RA, Waldrop AE, Smith A, Reeves S, Brady KT. Prescription opioid aberrant behaviors: a pilot study of sex differences. Clin J Pain 2009;25(6):477-84. CrossRef

92. Butler SF, Fernandez K, Benoit C, Budman SH, Jamison RN. Validation of the revised Screener and Opioid Assessment for Patients with Pain (SOAPP-R). J Pain 2008;9(4):360-72.

93. Koyyalagunta D, Bruera E, Aigner C, Nusrat H, Driver L, Novy D. Risk stratification of opioid misuse among patients with cancer pain using the SOAPP-SF. Pain Med 2013;14(5):667-75.

94. Anghelescu DL, Ehrentraut JH, Faughnan LG. Opioid misuse and abuse: risk assessment and management in patients with cancer pain. J Natl Compr Canc Netw 2013;11(8):102331.

95. Boscarino JA, Rukstalis M, Hoffman SN, Han JJ, Erlich PM, Gerhard GS, et al. Risk factors for drug dependence among out-patients on opioid therapy in a large US health-care system. Addiction 2010;105(10):1776-82. CrossRef 
96. Baldacchino A, Gilchrist G, Fleming R, Bannister J. Guilty until proven innocent: a qualitative study of the management of chronic non-cancer pain among patients with a history of substance abuse. Addict Behav 2010;35(3):270-2. CrossRef

97. Compton P. Should opioid abusers be discharged from opioid-analgesic therapy? Pain Med 2008;9(4):383-90. CrossRef

98. Compton P. Managing a drug abuser's pain. Nursing 1999;29(5):26-8. CrossRef

99. Passik SD, Kirsh KL, Donaghy KB, Portenoy RK. Pain and aberrant drug-related behaviors in medically ill patients with and without histories of substance abuse. Clin J Pain 2006;22(2):173-81. CrossRef

100. Passik SD, Portenoy RK, Ricketts PL. Substance abuse issues in cancer patients. Part 1: Prevalence and diagnosis. Oncology (Williston Park) 1998;12(4):517-24.

101. LeQuang J, Pergolizzi J. Chemotherapy-induced peripheral neuropathy: review of clinical studies. Boca Raton, Florida: CRC Press; 2012. 